TITLE:

Primary Process in the Direct Action of Ionizing Radiation on Proteins; Electron Paramagnetic Resonance of a Glycylglycine Single Crystal $\gamma$-Irradiated at $77^{\circ} \mathrm{K}$ ( Abstract_要旨)

\title{
AUTHOR(S):
}

\section{Morishima, Hiroshi}

\section{CITATION:}

Morishima, Hiroshi. Primary Process in the Direct Action of lonizing Radiation on Proteins; Electron Paramagnetic Resonance of a Glycylglycine Single Crystal $\gamma$-Irradiated at $77^{\circ} \mathrm{K}$. 京都大学, 1970, 理学博士

ISSUE DATE:

1970-11-24

URL:

http://hdl.handle.net/2433/213513

RIGHT: 


\section{【29】}

氏 名

学位の種 類 学位記 番号 学位授与の日付 学位授与の要件 研究科・専攻 学位論文題目

論文調查委員

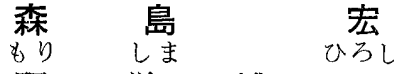

理学 博士

理 博 第 196 号

昭和 45 年 11 月 24 日

学位規則第 5 条第 1 項該当

理 学 研究科化学専攻

Primary Process in the Direct Action of Ionizing Radiation on Proteins ; Electron Paramagnetic Resonance of a Glycylglycine Single Crystal $\gamma$-Irradiated at $77^{\circ} \mathrm{K}$

（タンパク質に刘する電離放射線の直接作用に怙ける初期過程 $: 77^{\circ} \mathrm{K}$

で $\gamma$ 線照射されたグリシルグリシン単結晶の電子常磁性共鳴) (主查)

\section{論文内容 要旨}

放射線の照射によって固体のタンパク筫に生成する安定な遊離基には不対電子がイオウ原子上に局在す るもの之炭素原子上に局在するもの上の二種がある。

本論文は，イ才ウ遊離基以外のもう一つの安定遊離基，すな⿰七丂口炭素逰離基，- $\mathrm{NH}-\dot{\mathrm{C}} \mathrm{H}-\mathrm{CO}-$ ，の生成 する過程を明らかにするために，タンパク質のもっとむ単純なモデルであるグリシルグリシンの単結晶を 用いて，低温に抢いて $\gamma$ 線を照射した際に生成する遊離基についてEPR法による研究を行ない。低温にお いて不安定な前駆体遊離基が存在するととを見出し，乙れが熱あるいは光によって安定な遊離基へ転換す ることを証明した。グリシルグリシン単結晶に， $77^{\circ} \mathrm{K}$ ，暗所で ${ }^{60} \mathrm{Cor}$ 線 $10^{6} \mathrm{rad}$ を照射し，生成した遊離 基の EPR スペクトルを測定して，その構造を明らかにするとともに熱あるいは光に対する挙動を研究し た。 $77^{\circ} \mathrm{K}$ ，暗所に扔いて観測されるスぺクトルは主として三重線であるが，磁場の方向によって超微細 構造は複雑な变化を示した。とのスペクトルの特徴を解析し，X線解析の結果を参照するととによって， とのスペクトルを示す遊離基は二つの $\alpha$ プロトンをもつものであって, 超微細結合テンソルの主值として, $\mathrm{A}_{\mathbf{x}}=17, \mathrm{Ay}=27, \mathrm{~A}_{\mathbf{z}}=9(\mathrm{G})$ がもとめられ， $\mathrm{NH}^{+}{ }_{3}-\mathrm{CH}_{2}-\mathrm{CO}-\mathrm{NH}-\mathrm{CH}_{2}$ なる構造をもつ遊離基が推定さ れた。昇温によもなってとのスペクトルは二重線に変化し，スペクトルの特徴と超微細結合テンソルとか ら，このスペクトルを示す遊離基は $\mathrm{NH}^{+}{ }_{3}-\mathrm{CH}_{2}-\mathrm{CO}-\mathrm{NH}-\dot{\mathrm{CH}}-\mathrm{COO}^{-}$であると同定された。また可視光の照 射によっても同様のスペクトルが得られ同じ遊離基に変化していることが確められた。この過程は初めに 生成する不安定種に関する一次反応であるととが示された。これらの結果に基づいてとの不安定の遊離基 が熱あるいは光によって安定な炭素の遊離基に転換する機構を提出した。

参考論文その 1 はポリグリシン，ポリアラニン，ポリグルタミン酸に低温で ${ }^{60} \mathrm{CO} \gamma$ 線を照射して， EPR スペクトルを観測し，また昇温にともなう遊離基量の変化から，不安定遊離基と安定遊離基上の転換を明 らかにしたものである。

その 2 はオキシへモグロビン, メトヘモグロビン, グロビン, グロビンーヘミン混合物, 执よびヘミン 
に，低温で放射線を照射し，観測される EPR スペクトルを解析した結果，放射線による損傷はタンパク 質部分に起っていることが明らかにされたものである。

その 3 はタンパク質に対する放射線の直接作用の研究のために，ポリアミノ酸，ペプチド，アミノ酸単 結晶など，単純なモデル系を用い，低温に扔ける遊離基の同定执よび昇温により安定ラジカルに転換する 過程をEPRを観測するととによって追求したものである。

その 4 はイソプレノイド生合成の中間体と考えら机るメバロン酸, メバロラクトン执よびそのリン酸エ ステルの定性，定量分析法に関するものであり，またその 5 はブドウ状球菌の無細胞抽出酵素を用い， 2 - ${ }^{14} \mathrm{C}$ 一メバロン酸から，イソペンテニルピロリン酸を生成させ，メバロン酸の 2 位置の炭素はイソペンテ ニル基のメチレンの炭素となることを確認したものである。

\section{論交審查の結果の要旨}

生体に対する放射線の直接作用を解明するために放射線の照射によって固体タンパク質に生成する遊離 基について，電子常磁性共鳴（EPR）法による研究が主しして常温において行なわれてきた。その結果， 安定な遊離基には不対電子がイオウ原子上と炭素原子上とに局在する 2 種があって，一つはシスティン残 基上の- $\mathrm{NH}-\mathrm{CH}\left(\mathrm{CH}_{2}-\dot{\mathrm{S}}\right)-\mathrm{CO}$ 一型，もう一つはグリシン残基上のー $\mathrm{NH}-\dot{\mathrm{C}} \mathrm{H}-\mathrm{CO}$ 一型であるとと が明らかにされてきた。しかしながらタンパク質は約 20 種のアミノ酸よりなる分子量約 1 万以上の高分子 であり，また放射線は分子のいずれの部分にも影響を与えるととが予想されるので，てのように特定の残 基に局在した形の損傷が一般的にあらわれるととは不思議に思われてきたととであった。液体窒素温度や 液体ヘリウム温度のような低温で照射し，測定すると室温と異なるスペクトルがしばしば観測されるとと ろであり，乙のととは，上記の損傷の選択性を解明するために，低温において谏結された過程㧍よび温度 変化に伴う過程に関する研究が有効であるととを示唆している。上述のイオウ遊離基に関してはすでにシ スチン単結晶について低温でS一S結合にイオン遊離基が生成し，昇温にともなっててれが安定な一弄型遊 離基に転換するととが明らかにされてきた。

イオウ遊離基外のもう一つの安定遊離基，すな⿰ち炭素遊離基，一 $\mathrm{NH}-\dot{\mathrm{CH}} \mathrm{CO}-， の$ 生成する過程 は申請論文によってはじめて明らかにされたものである。主論文はタンパク質のもっよも単純なモデルで あるグリシルグリシンの単結晶を用いて，低温においては不安定な前駆体遊離基が存在するととを見出 し，乙れが熱あるいは光によって安定な遊離基へ転換するものであるととを証明したものである。

グリシルグリシン単結晶に, 低温暗所で ${ }^{60} \mathrm{Co}$ 線を照射し, 生成した遊離基の EPRスペクトルを測定する と主として三重線より成るスペクトルが観測され，その超微細構造は磁場の方向によって，複雑な変化を 示した。このスペクトルの特徴の解析の結果とのスペクトルを示す遊離基は, $\mathrm{NH}_{3}{ }_{3}-\mathrm{CH}_{2}-\mathrm{CO}-\mathrm{NH}$ $\dot{\mathrm{C}} \mathrm{H}_{2}$ なる構造をむつものと推定され，乙れが昇温にとあなって二重線スペクトルに変化することから $\mathrm{NH}^{+}$ - $\mathrm{CH}_{2}-\mathrm{CO}$ - $\mathrm{NH}-\dot{\mathrm{CH}}$ - $\mathrm{COO}$ なる構造をむつ遊離基に変化するあのであるととが示された。また可視光 の照射によっても同様のスペクトルが得られ同じ遊離基に変化しているとよが確められている。この過程 は初めに生成する不安定種に関する一次反応であるととが示され，乙の不安定遊離基が熱あるいは光によ って安定な炭素の遊離基に転換する機構を提出している。 
この機構は，本実験において観測された事象をよく説明するとともに，乙の機構に従えば，さらに参考 論文に扣いて行なわれた研要の結果をあよく理解するてとができる。との結果は從来報告されてきた多く のタンパク質におけるグリシン残基上の遊離基の生成の機構をよく説明しうるものである。

参考論文はいずれ屯ポリグリシン，ポリアラニン，ポリグルタミン酸，オキシへモグロビン，メトへモ グロビン，グロビン，グロビンーヘミン混合物及びヘミンなどに低温で ${ }^{60} \mathrm{Co}$ 線を照射して，EPRスペク レルを観測し遊離基の生成上その転換，消失を証明し，タンパク質に㧍ける放射線の直接作用を明らかに する基礎的知見をえたものである。またイソプレノイド生合成の中間体と考えられるメバロン酸，メバロ ラクトンおよびそのリン 酸エステルの定性, 定量分析法を報告しブドウ状球菌の無細胞抽出酵素を用 い，これらの生合成機構解明の研究を行なったものである。

要するに, 申請者はタンパク質に㧍けるラジカルの生成之転換について研究し放射線の直接作用の機構 について数々の興味ある貴重な知見を生体高分子化学亡磁気共鳴の分野に加え，この研究領域の発展に寄 与するところが少なくない。また主論文, 参考論文を通じて申請者が生体高分子化学および物理化学に豊 富な知識之優扎た研究能力上をむっているととを認めることができる。 よって，本論文は理学博士の学位論文として価值あるものと認める。 